\title{
Analysing the Role of Visions, Agency, and Niches in Historical Transitions in Watershed Management in the Lower Mississippi River
}

\author{
Tom van der Voorn ${ }^{1, *(1)}$ and Jaco Quist ${ }^{2}$ \\ 1 Institute of Environmental Systems Research, University of Osnabrück, Barbarastr. 12, \\ D49069 Osnabrück, Germany \\ 2 Faculty of Technology, Policy, Management, Delft University of Technology, P.O Box 5015, \\ 2600 GA Delft, The Netherlands; J.N.Quist@tudelft.nl \\ * Correspondence: tvanderv@uni-osnabrueck.de; Tel: +49-(0)541-696-3348
}

Received: 14 November 2018; Accepted: 10 December 2018; Published: 13 December 2018

\begin{abstract}
This paper analyses five major transitions in watershed management in the Lower Mississippi River from the early 19th century to the present. A conceptual framework is developed for analysing the role of visions, agency, and niches in water management transitions and applied to a historical case on water management in the Lower Mississippi River. It is shown that water management regimes change over time and that major transitions were preceded by niches, in which new visions were developed and empowered. The case shows that: (i) emerging visions play an important role in guiding transitions; (ii) agency enables the further diffusion of visions and niches; (iii) vision champions play an important role in transitions, but are not decisive; (iv) each transition has led to an extension of the number of societal functions provided, which has led to more complex water management regimes in which functions are combined and integrated; and (v) external landscape factors are important, as they can lead to awareness and urgency in important decision making processes.
\end{abstract}

Keywords: transitions; water management regimes; water resource management; niches; visions; agency

\section{Introduction}

From the 20th century onwards, the management of water resources has undergone at least four major paradigm shifts [1]. At the beginning of this century, the dominant paradigm was single purpose water resources management in all industrialised countries. This means that each water resource was managed for a specific purpose. For example, streams were harnessed for generating hydroelectric power. Fields were irrigated from canals and diversion or storage reservoirs. Cities were served with domestic water from wells and storage dams, and streams were rendered navigable by channel works. However, this was done without taking the interconnectedness of different functions of rivers into account [2]. By the 1930s, the prevailing paradigm had become multi-purpose water resource management, which aimed at combining functions of rivers. In this period, it had become possible to build dams to generate hydroelectric power, while also storing water for other purposes like agricultural irrigation, increasing the security of fresh water and water safety.

By the 1970s, a third paradigm emerged, due to the growing awareness of the full social and environmental impacts of river management re-shaping the natural landscape [3]. This led to the implementation of more environmentally sound forms of water engineering approaches like floodplain management and conservation. All three paradigms were technocratic as they assured high predictability and controllability of the water systems to be managed. However, they failed to account 
for the complexity and strong interconnectedness of social and ecological components of these systems, also in disregard of potential risk of causing unexpected or unintended consequences [4-6].

By the 1990s, thinking about water management entered a fourth period [7], as the shortcomings of the prevailing water management paradigms became evident. A key change was that water systems were increasingly characterised as complex adaptive systems, which are not only self-organising, but also unpredictable and non-linear in their response to intervention what further complicates their management [8]. New and more integrated and adaptive water management approaches have been developed and are still being implemented to compensate for the perceived shortcomings in earlier management approaches [9].

The discussion above makes it clear that water management regimes have evolved over decades, and changing them requires time $[8,10,11]$. It includes changing their underlying paradigm-the set of guiding principles determining the internal logic of water management regimes and depends on the emergence of novel visions that provide guidance and orientation. Transitions in water management are complex processes, in which visions and actors play a vital role that needs further investigation to better understand and manage future transitions, for instance, toward adaptive water management regimes.

The relevance of guiding visions has been recognised in (sustainable) technology development [12], in system innovations towards sustainability [13] and in transition studies [13-17]. Despite increasing popularity of visioning approaches in the past two decades, theory development on the guiding potential of visions is still limited [18]. Much is known on how transitions are preceded by niche developments [19], but little is known how alternative visions emerge and further guide the development of niches and novel societal functions. As little research has been conducted on niche developments in successive transitions, our purpose is to provide more insight into such transitions based on a historical case on water management in the Lower Mississippi River. The aim of the paper is to develop and apply a framework for analysing water management transitions and emerging visions and niches and to enhance our understanding on: (i) what is the role of emerging visions and niches in such transitions and (ii) what is the role of agency and how does it relate to vision development and niche formation?

The paper is structured as follows: Section 2 presents an overview of various theoretical perspectives in the literature on transitions, agency and visions, which provides the theoretical foundation of our conceptual framework. Section 3 presents an inquiry into historical transitions in watershed management in the Lower Mississippi River, which analyses water management transitions covering several transitions in a time span over more than two centuries. Section 4 discusses major lessons from this inquiry, followed up with concluding remarks in Section 5.

\section{Materials and Methods}

\subsection{Theory}

\subsubsection{Multi-Level Perspective and Socio-Technical Transitions}

A major analytical lens associated with the transitions approach is the Multi-Level Perspective (MLP) that explains transitions by the interplay of dynamics at three levels (see Figure 1) [20-22]. These are the levels of niches, socio-technical (ST) regimes, and landscape. The MLP takes as a starting point that novelty emerges and develops at the niche level, which eventually can result in transformation or replacement of ST regimes. Regimes can be conceptualised as consisting of actors, institutions, and (socio-technical) systems [23]. At the landscape level, gradual developments and sudden shocks like natural disasters or economic crises might put pressure on existing ST regimes and may create windows of opportunity for niches to break through.

The emphasis in transition studies is generally on ST-transitions in provision systems that relate to one or multiple societal functions like water supply [24,25], food, or energy [19] These systems provide products and services to users through companies and markets and the focus is on the emergence 
and the rise of new technologies that bring new functionalities. The nature of change in ST-systems is evolutionary and path-dependent, while the dynamics of such systems are subject to risk and uncertainty, and thus inherently unpredictable. Geels and Schot [26] have argued that transitions can only take place if a niche is sufficiently developed to take advantage of a window of opportunity. In the MLP, niches represent alternative socio-technical configurations, which are not yet institutionalised but are potentially embryonic nuclei for the future. Other related types of niches can be found in the literature, ranging from backcasting niches [27] to technological niches [28], transition experiments [29], and market niches [30].

\subsubsection{Social-Ecological Transitions and Management Regimes}

In addition to the sociotechnical perspective on transitions discussed in Section 2.1.1, there is a social-ecological perspective on sustainability transitions [17,31], which has similarities and differences with the ST-perspective. The similarities include that both perspectives conceptualise transitions as nonlinear disruptive systemic changes. The central notion in both perspectives is the concept of regime, which refers to a dominant and stable configuration in one of these systems [17]. Like ST-systems, a social-ecological system (SES) can be considered as complex adaptive systems, characterised by complex, dynamic, multiscale, nonlinear, and adaptive properties posing common challenges to the regimes in governing transitions in these systems [31]. The concept of SES is used to emphasise interconnectedness of social and ecological systems through human and natural elements that are closely interacting and mutually constituting [32], which is the case in water systems.

Similar to ST-regimes, water management regimes cover a wide range of interdependencies among actors and institutions, including the power relations and role constellations between different actors $[33,34]$.

However, the ST and social-ecological perspectives conceptualise transitions in a different way, due to a different focus, unit of analysis, and system delineation. Social-ecological transitions relate to a large variety of human-ecosystem interactions that weaken or strengthen an ecosystem's resilience, which is its ability to withstand shocks, while maintaining its function, and transform, anticipating external pressures, shocks, and threats [35,36]. The focus is on supporting resilience in existing system, or transform ecosystems into more desirable systems [37]. Regimes dedicated to the management of SES are place-bound as they are embedded in a SES that provides the main unit of transition analysis, whereas ST-regimes operate simultaneously across clearly demarcated industrial sectors with multiple localities [31]. Each management regime implicates different patchworks of SES through resource extraction, service consumption and waste assimilation.

Another difference entails the nature of the regime. Rather than using the term social-ecological regimes as proposed by Fischer-Kowalski [38], we propose that the challenges of managing SES, for which technology can be used, can be associated with the notion of management regime. Management regimes provide stability of ecosystems by enhancing their capacity to deal with disturbances through transformation [17]. To govern social-ecological transitions, agency is needed just like in socio-technical transitions. A management regime can be seen as a conceptual configuration of social and ecological elements that condition human-ecosystem interactions, whereby ST-regimes can help to sustain SESs through technologies [31]. After Smith [31], we consider a management regime to encompass a patchwork of different ST-systems that evolve around a SES, which is typically rooted in a particular spatial context such as a watershed e.g., land-use management, waste management, resource management, and environmental management.

\subsubsection{Water Management Regimes}

Within the confines of water management, a management regime is embedded in a SES. Water management regimes have evolved around a particular SESs that provides essential ecosystem services (e.g., water). The emphasis in management regimes is on managing societal functions generally considered as public tasks. This focus is reflected in the definition of water management regime by 
Pahl-Wostl [8] (p. 8): "the whole complex of technologies, institutions, environmental factors, and paradigms that are highly interconnected and essential to the functioning of the management system that is targeted to fulfil a societal function such as water supply or flood protection". Paradigms refer to a set of guiding principles for water management [39].

Water management regimes are generally about balancing different and sometimes conflicting societal functions and interests, taking a public or governmental perspective. Water management regimes are not solely meant for delivering water-related products and providing functions to end-users. They are also about managing societal functions related to water that are relevant for several ST-regimes. Water management not only concerns flooding protection, but also transportation, water quality, production of drinking water, as well as water for industry and agriculture.

\subsection{Visions in Niches and Transitions}

\subsubsection{Visions}

Visions are considered important for transitions because they provide a common reference point for action and guide actors in their actions and behaviour in reaching out to that point [13-17]. Various vision concepts can be found in the literature on innovation studies and transitions towards sustainability, while distinction is made between different levels like niches or projects (micro), networks and sector (meso), and society at large (macro) [27]. Various authors e.g., Smith et al. [40] have emphasised the important role of guiding visions in transitions. In transition management, visions are referred to as: "a framework for formulating short-term objectives and evaluating existing policy $(. .$.$) these visions must be appealing and imaginative and be supported by a broad range$ of actors" Rotmans et al. [41] (p. 23). Most vision concepts address emerging phenomena like the development and diffusion of new technologies, the rise of new scientific disciplines and transitions towards sustainability [13]. Alternative visions like sustainability visions [13] or climate change adaptation futures $[42,43]$ are backed by alternative trend-breaking expectations about possibilities and may be based on different alternative worldviews.

Visions emerge in different contexts (e.g., organisation, communities, research projects) and shapes, but show three common aspects [18]: an image of the future, an ideal, and a desire for deliberate change. These aspects reflect the guiding potential of visions. Building on Grin [44], Quist et al. [45] and van der Helm [18], we define a guiding vision as a shared multi-actor construction of a desirable future that may have the potential to guide actors in their actions and behaviour to bring about that future, especially when generated in a participatory process. Visions can become more guiding once they are shared by a growing group of actors.

\subsubsection{Agency}

Agency is widely considered key to emerging visions and niches [13]. Emerging visions are connected to actors and networks that can either endorse or contest visions and when the vision changes the supporting network may change too (and vice versa). Actors can provide agency, influencing the speed and direction of transitions [34,46,47]. For agency in water management transitions we build on Smith et al. [40], who describe agency in transitions as the capabilities of actors to intervene and alter the balance of selection pressures bearing on a regime and their adaptive capacity.

Building on the guiding vision, which was originally proposed as the German Leitbild concept [48,49], Quist [13] has introduced the concept of a vision champion, which is a key individual or a group of key persons who are able to motivate and coordinate the collective pursuit of change. A vision champion can play a vital role in realising major change like policy entrepreneurs who are individuals that instigate, implement and sometimes block transitions [50-52], or system builder-entrepreneurs who lead and manage development and further growth of the large technical systems [53]. It should be noted that such key persons or key groups are often embedded in informal networks, typically governed by not yet institutionalised rules. Such networks are in the beginning 
informal and flexible in terms of membership, role, power of actors and connections, but their members can also be active in more formalised networks. Niches are created for setting up experiments and steering directions of experimenting, learning innovations, and adaptation, which are mechanisms that underlie transitions [15]. These mechanisms relate experiments to other niches, either within or outside the domain or function of the experiment [29]. Therefore, niches are closely connected to formal and informal networks, as they enable learning processes for (radical) innovations by providing access to new kinds of knowledge and supporting multiple ways of interpretations.

Emerging visions can be seen as seeds for change (co-) shaped by a range of actors, that challenge rules that are deeply entrenched in existing structures and the actors supporting and protecting such structures [44]. Visions are emerging phenomena, guiding activities, and changes that eventually may alter the dominant regime [13]. Emerging visions are usually rooted in entirely different beliefs, values and mental frameworks initially not shared by larger groups in society [13]. Such visions are typically associated with outsiders, who are likely to conduct rule-breaking behaviour [54,55], because they pursue divergent and sometimes marginal perspectives [56]. Learning is key to vision development and niche formation [13], but our focus is more on the interaction of visions and actors in niches and less on learning processes and knowledge.

\subsection{Framework and Methodology}

\subsubsection{Conceptual Framework}

Building on the theoretical perspectives presented in the previous sections, we develop a conceptual framework for analysing water management transitions. The framework builds on the MLP, as it provides a base for conceptualising the interplay of niches, visions, and agency. Following the MLP, Transitions are the outcomes of alignments and de-alignments between processes at the niche, regime and landscape level, which in turn enables the breakthrough of a niche. This requires the empowerment of the niche, in which visions and actors play a key role.

Our framework builds on the interplay of visions and actors to describe niche-driven change in water management regimes. The principal mechanism for such changes is triggered by alternative visions that emerge in niches, linked to supportive networks of actors, providing agency (see Figure 1). Actors develop niche visions, which introduce new guiding principles for water management that challenge the established rules e.g., the dominant guiding principles for water management. Actors need to support the niche visions, which evolve together with the development and testing of novelties in the niche through niche experiments. The niche vision that becomes shared and adopted by actors further guides the development of a niche and the actions of actors in the network to further empower the niche to challenge existing rules of the regime. The replacement of rules leads to a transition.

Based on the theoretical concepts discussed in Section 2, Table 1 shows the variables and evaluation criteria for each of the dimensions of our framework.

Table 1. Evaluation criteria of niche-driven innovations.

\begin{tabular}{|c|c|c|}
\hline Dimension & Variable & Criteria \\
\hline Landscape & Landscape factors $[22,23]$ & $\begin{array}{l}\text { What were important gradual and } \\
\text { disruptive developments? }\end{array}$ \\
\hline Regime & $\begin{array}{l}\text { Societal functions }[24,25] \\
\text { Guiding principle(s) for water management }\end{array}$ & $\begin{array}{l}\text { What were the societal functions? } \\
\text { What were the dominant guiding } \\
\text { principle(s) for water management? }\end{array}$ \\
\hline Niche & $\begin{array}{c}\text { Niche vision [18] } \\
\text { Guiding principle(s) for water management } \\
\text { Agency [13] }\end{array}$ & $\begin{array}{l}\text { What was the desired change? } \\
\text { What were the new guiding principle(s)? } \\
\text { Who provided agency? }\end{array}$ \\
\hline
\end{tabular}




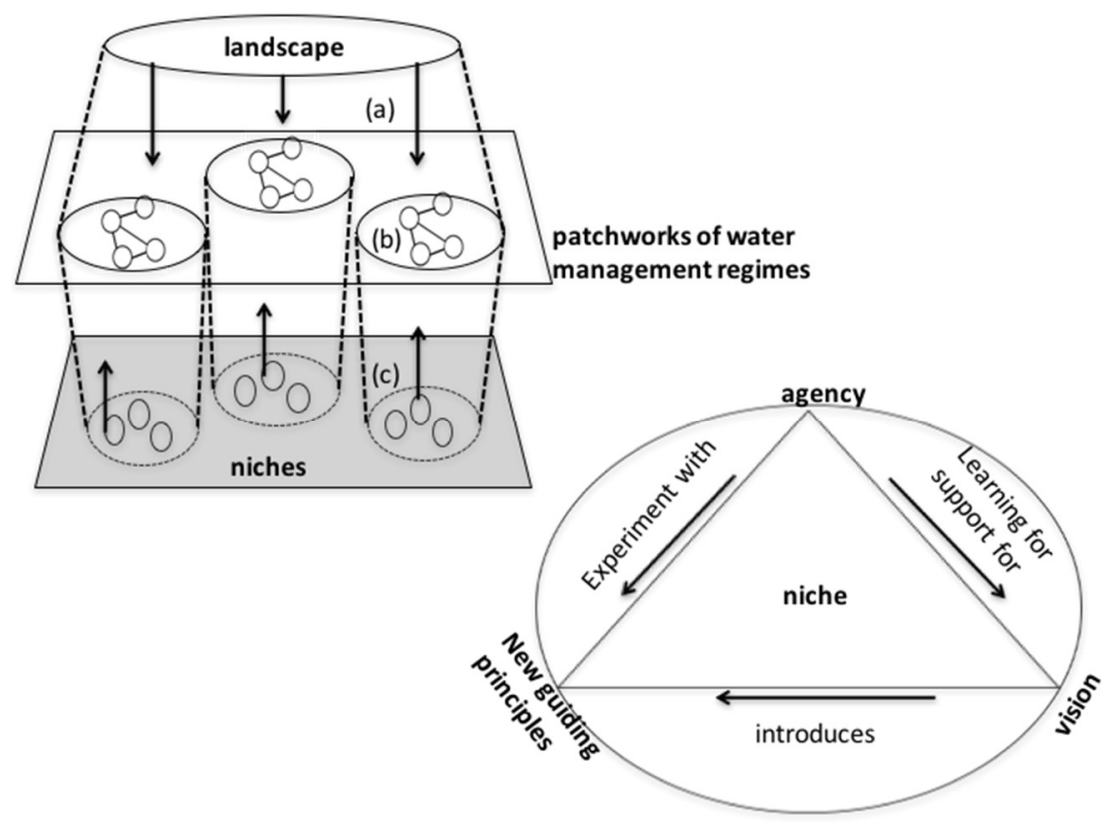

Figure 1. A graphical representation of mutual relationships between visions, guiding principles, and actors in niche-driven change in water management regimes.

\subsubsection{Research Methodology}

A qualitative historical single-case study allows for learning from historical transitions, by studying processes and tracing specific causal-event chains within their own context [57]. Transitions are complex processes of multiple conjunctures of causal conditions in time and space, yielding a given outcome. Even though causality may exist, it remains quite difficult to clearly indicate the cause producing the outcome of interest [57,58]. The relevance of the Lower Mississippi River lies in its rich history of major flood disasters and damages in conjunction with a wide array of enactments by US Congress and policy developments and the wide availability of secondary historical sources that report on these events [59].

We here use causal narratives that explain certain outcomes of sequences of historical events, which are tied together by a central theme. Causal narratives help us to trace unfolding processes and study event sequences, timing, and conjunctures [60]. Our interest lies in the interplay of factors and influences across the landscape, regime and niche level. Each narrative captures complex interactions between agency and visions (niche level) and changing contexts (landscape and regime level), time, event sequences, making moves in games, and changing identities. However, causal narratives need to be guided by 'heuristic devices' that specify a certain plot [61]. The principal mechanism for niche-driven regime change will be used as a central plot for our narratives.

\subsubsection{Data Sources}

Secondary historical sources such as scholarly books and papers are used to draw the overall picture and patterns over a much longer period of time. Geels [61] emphasises the exploratory and illustrative character of transition studies. In transition research, it is common practice to use secondary sources and to use a framework as a lens to look at these sources in a transparent and systematic way see e.g., [22,62-64].

We applied data triangulation to construct our narratives with a beginning, middle, and an end, focusing on historical events as well as on underlying factors see e.g., [65]. Triangulation involved the comparison of various historical accounts i.e., [3,66-68] to determine the appropriate time span for each narrative. Our inquiry and data triangulation is based on multiple interpretations extracted from 
secondary sources. We will evaluate and compare the narratives in terms of the criteria presented in Table 1 to identify recurring patterns.

\section{Results: A Case Study on the Lower Mississippi River}

\subsection{Historical Context}

Floods were part of the earliest recorded history of the Mississippi River. Since its foundation in 1718, New Orleans has been the epicentre of floods, resulting from both hurricanes and extreme run-offs of the Mississippi River. About eleven flood events occurred on the Mississippi between 1849 and 2001, with catastrophic floods in 1927, 1936, 1973, and 1993 labelled significant enough to merit regional or national attention. From the settlements in the State of Louisiana in the early 1700s until the early 20th century, the principal and often only approach to flood damage reduction was the construction of levees. These flood disasters and the associated policy responses have played an important role in the evolution of US watershed management. Watershed management is a management planning process that seeks to balance healthy ecological, economic, cultural, and social conditions within a watershed, whereas water resources management includes the management related only to water resources [69].

Following Sabatier [3], our historical inquiry covers five consecutive transition periods, which cover the key eras of water(shed) management in the US: the Manifest Destiny Era (early 1800s-1889), the Progressive Conservation Era (1890-1928), the Federalism and New Deal Era (1929-1967), the Environmental \& Flood Insurance Era (1968-1994), and the Watershed Collaborative Era (1995-present). Results for each period are summarised in Table 2.

Table 2. Summary table of transition periods.

\begin{tabular}{|c|c|c|c|c|c|}
\hline \multirow[b]{2}{*}{ Criteria } & \multicolumn{5}{|c|}{ Transition Period } \\
\hline & $\begin{array}{c}\text { Manifest Destiny } \\
\text { Era (Early } \\
\text { 1800s-1889) }\end{array}$ & $\begin{array}{c}\text { Progressive } \\
\text { Conservation Era } \\
(1890-1928) \\
\end{array}$ & $\begin{array}{c}\text { Federalism and } \\
\text { New Deal Era } \\
(1929-1967)\end{array}$ & $\begin{array}{l}\text { Env. \& Flood Ins. Era } \\
(1968-1994)\end{array}$ & $\begin{array}{c}\text { Watershed } \\
\text { Collaborative Era } \\
\text { (1995-Present) }\end{array}$ \\
\hline \multicolumn{6}{|c|}{ Dimension 1: Landscape factors } \\
\hline $\begin{array}{c}\text { Gradual } \\
\text { developments }\end{array}$ & $\begin{array}{l}\text { Increased land-use } \\
\text { for agriculture }\end{array}$ & $\begin{array}{c}\text { Increased } \\
\text { environmental } \\
\text { awareness }\end{array}$ & $\begin{array}{l}\text { Strong state-based } \\
\text { federalism }\end{array}$ & $\begin{array}{l}\text { Increased floodplain } \\
\text { occupancy }\end{array}$ & $\begin{array}{l}\text { Increased vulnerability } \\
\text { to flood disasters }\end{array}$ \\
\hline $\begin{array}{l}\text { Disruptive } \\
\text { events }\end{array}$ & $\begin{array}{c}\text { The } 1849 \& 1850 \\
\text { floods/The } 1849 \& \\
1850 \text { Swamp Land } \\
\text { Acts }\end{array}$ & $\begin{array}{l}\text { The } 1927 \text { flood } \\
\text { disaster }\end{array}$ & $\begin{array}{l}\text { The Great } \\
\text { Depression }\end{array}$ & $\begin{array}{l}\text { The } 1993 \text { flood } \\
\text { disaster/NFIP }\end{array}$ & The 2005 flood disaster \\
\hline \multicolumn{6}{|c|}{ Dimension 2: Regime } \\
\hline $\begin{array}{l}\text { Societal } \\
\text { functions }\end{array}$ & $\begin{array}{l}\text { Drinking water } \\
\text { supply, waste } \\
\text { disposal, } \\
\text { hydropower, } \\
\text { navigation }\end{array}$ & $\begin{array}{l}\text { Drinking water } \\
\text { supply, waste } \\
\text { disposal, } \\
\text { hydropower, } \\
\text { navigation, flood } \\
\text { control }\end{array}$ & $\begin{array}{l}\text { Drinking water } \\
\text { supply, waste } \\
\text { disposal, } \\
\text { hydropower, } \\
\text { navigation, flood } \\
\text { control, land use } \\
\text { planning }\end{array}$ & $\begin{array}{l}\text { Drinking water supply, } \\
\text { waste disposal, } \\
\text { hydropower, } \\
\text { navigation, flood } \\
\text { control, land use } \\
\text { planning, flood plain } \\
\text { based flood control }\end{array}$ & $\begin{array}{c}\text { Drinking water supply, } \\
\text { waste disposal, } \\
\text { hydropower, } \\
\text { navigation, flood } \\
\text { control land use } \\
\text { planning, flood plain } \\
\text { based flood control, } \\
\text { wetland based flood } \\
\text { control. }\end{array}$ \\
\hline $\begin{array}{l}\text { Dominant } \\
\text { guiding } \\
\text { principle }\end{array}$ & $\begin{array}{l}\text { Single-purpose } \\
\text { approach for } \\
\text { navigational } \\
\text { enhancement }\end{array}$ & $\begin{array}{l}\text { Single-purpose; } \\
\text { Levee based Flood } \\
\text { control }\end{array}$ & $\begin{array}{l}\text { Multi-purpose } \\
\text { watershed } \\
\text { management } \\
\text { (systematic } \\
\text { management of } \\
\text { rivers) }\end{array}$ & $\begin{array}{l}\text { Multi-purpose } \\
\text { watershed } \\
\text { management; } \\
\text { Flood control } \\
\text { engineering \& multiple } \\
\text { adjustments, flood } \\
\text { insurance }\end{array}$ & $\begin{array}{l}\text { Multi-purpose \& } \\
\text { collaborative } \\
\text { watershed } \\
\text { management based on } \\
\text { IWRM principles }\end{array}$ \\
\hline \multicolumn{6}{|c|}{ Dimension 3: Niche } \\
\hline Niche visions & $\begin{array}{l}\text { Reservoirs for flood } \\
\text { control (Ellet) } \\
\text { Levees for flood } \\
\text { control (Humphreys) } \\
\text { Jetties for flood } \\
\text { control (Eads) }\end{array}$ & $\begin{array}{l}\text { land use planning } \\
\text { for comprehensive } \\
\text { watershed } \\
\text { management } \\
\text { (Hoover) }\end{array}$ & $\begin{array}{l}\text { Human } \\
\text { adjustments to } \\
\text { floods } \\
\text { (White) }\end{array}$ & $\begin{array}{l}\text { Floodplain restoration } \\
\text { (Galloway) Wetland \& } \\
\text { floodplain restoration } \\
\text { (Kusler) }\end{array}$ & $\begin{array}{l}\text { Adaptive water } \\
\text { management and } \\
\text { disaster resilience }\end{array}$ \\
\hline
\end{tabular}




\subsection{The Manifest Destiny Era (Early 1800s-1889)}

\subsubsection{Landscape Developments}

The Manifest Destiny is a term for the period of American expansion where the US was destined to stretch from coast to coast in the 19th century. In this period, land was heavily exploited, especially in the West of the US. Due to disruptive events like the large floods of 1849 and 1850 in the Lower Mississippi Valley, US Congress enacted the Swamp Land Acts of 1849 and 1850. This gave rise to a gradual development of millions of acres for agricultural use, ultimately exacerbating the flood problem [70].

\subsubsection{The Existing Regime}

Although watershed management was essentially absent in the Manifest Destiny Era, rivers and lakes were envisioned as a source for fuelling economic development [3]. Property usable to waterpower was seized by private concerns. Mining companies practiced improper and wasteful mining practices. The overall societal function of water management comprised mainly the functions drinking water supply, waste disposal, hydropower, generally generated by dynamo water turbines, and navigation. In this single purpose era, these functions were not interconnected and managed separately. Without any attempts to reconcile or combine functions, water quality and habitat protection were on virtually no one's radar screen [3]. This principle was institutionalised in the engineering work of the US Army Corps of Engineers (hereafter referred to as the Corps), as the principal federal authority in water affairs. The aim of water management was to tame the river for navigational purposes and commercial interests, by controlling, diverting, and damming it. The dominant guiding principle for water management was a single-purpose approach of navigational enhancement of the Mississippi River, by removing obstructions from the channels of the river (boulders and snags).

\subsubsection{Niche Developments}

In this period, there were three niche visions on flood control: (i) building reservoirs, (ii) levees, and (iii) jetties for flood control. The key person for the first vision was Charles S. Ellet Jr., one of the best-known engineers of his time, who associated the growing flood problem with increased cultivation in the valley [71]. Ellet recommended the practicability and value of building reservoirs on the Mississippi's tributaries to reduce flooding. His vision and ideas were considered controversial and impracticable and were never adopted [67].

The second vision gained more support and was based on the most extensive study on the Lower Mississippi River ever undertaken at that time, by Andrew A. Humphreys and Henry L. Abbot, two officers from the Army Corps of Topographic Engineers. Their study addressed the environmental impact of over-exploitation of swamp and overflow land. Their pioneering work challenged existing hydraulic theories and introduced a new universal formula and a method to explain river flow. It provided the scientific base foundation for their vision that proposed a desired change towards levee-based flood control, targeted at realising levee construction along the Mississippi River [71]. Humphreys assumed that levees would not prevent the water from rising but, if sufficiently high, levees would prevent flooding.

Based on his new method for measuring and computing the river's discharge and flow, Humphreys proposed the new "levee-only" vision for flood control along the lower Mississippi. The novel vision was believed to achieve cost efficiency in flood control engineering. The novelty lies in the new guiding principle assuming that levees only could control flooding along the lower Mississippi River without costly reservoirs and river cut-offs [71]. When Humphreys became Chief of Engineers of the Corps in 1866, he played an important role in building a network and restructuring the Corps and its river engineering practices around the "levee-only" vision. Favourable factors for building support for his vision were: (i) private engineers and congressmen questioned the Corps' 
capabilities; (ii) the growth of professional engineering societies; (iii) increased demand of US Congress for public works projects.

The third vision was supported by the famous civil engineer James Buchanan Eads, who argued that levees would actually lower the bed of the river, as they would allow floodwater to scour a deeper channel. Eads envisioned that closing all gaps in the levees and then imposing a uniform width on the river by narrowing wide places through jetties would eventually secure a sufficient depth for navigation to yield levees unnecessary. Eads's successful accomplishments with jetties at the South Pass Channel triggered influential developments, which crumbled the Corps' responsibilities and reputation in river engineering. US Congress deprived the Corps from its right to conduct scientific expeditions in the West, after which it weakened the Corps' authority on the Mississippi River by establishing the Mississippi River Commission. The success of the jetties showed the Corp's incompetence in river engineering because its river engineering approach was based on the false assumption - that levees alone could adequately confine the Mississippi River [71]. This encouraged private civil engineers to break the Corp's monopoly on federal public works projects.

There was a fierce clash between the advocates of the second and third vision, which represented two river engineering schools. Due to commercial interests in navigation, the course of the dispute seemed to be determined in favour of the third vision supported by Eads. Ironically, despite Eads's successful accomplishments with jetties, the "levee-only" approach advocated by Humphreys became and remained the dominant guiding principle until the Great Flood of 1927 because many Corps officers supported this approach.

\subsection{The Progressive Conservation Era (1890-1929)}

\subsubsection{Landscape Developments}

During the Progressive Conservation Era, the over-exploitation of natural resources for private gain was a key factor for change. Being a disruptive event, the Great Flood of 1927 unmistakably revealed the shortcomings of the prevailing 'levee-only' guiding principle, which shifted public opinion towards liability of federal government for flood damage $[66,70]$. The flood caused over $\$ 200$ million in property damage (about $\$ 2$ billion in 2000 US dollars) [66]. The public's gradually growing critical awareness of natural resources and environmental developments like the over-exploitation of natural resources for private gain contributed to the growth of the Progressive conservation movement [72]. The Progressive Conservation movement was a coalition of reformers who believed in mankind's ability to improve the environment and conditions of life, an obligation to intervene in economic and social affairs.

\subsubsection{The Existing Regime}

The overall societal function of water management comprised the functions described in Section 3.2.2. In this period, the set of functions expanded with flood control that was driven by the dominant guiding principle of "levee only" based flood control. Due to the rise of the Progressive Conservation movement, there was a tendency to strike a balance between economic and environmental objectives [3]. In contrast to the federal level, the state and local levels were considered the appropriate levels at which water issues were tackled [70]. Emphasis was put on the ability of experts and in the efficiency of government intervention for federal supervision of the nation's waterways and their preservation of those resources for future generations.

\subsubsection{Niche Developments}

In this period, there was only one niche vision on federal government involvement in water affairs. The vision was strongly supported by Hoover, at that time the US Secretary of Commerce. The vision proposed a desired change towards treating each river as an integrated unit from source to mouth [68], targeting at realising multi-purpose water programmes. As a summer student-assistant, Hoover had become a strong supporter of the underlying philosophy of this vision by Stanford geography 
professor John Wesley Powell, who appealed in his innovative 1878 Report on the Lands of the Arid Region of the US for planned development of water and land resources in the country. He had been the first who defined a watershed as an area of land, a bounded hydrologic system, within which all living things are inextricably linked by their common water course and where, as humans settled, simple logic demanded that they become part of a community [73]. By the time Powell made his famous plea in 1890 for making local government boundaries coincide with hydrographical units, the jurisdictional decisions had long been made and he was ignored [3].

Inspired by the vision of Powell, Hoover supported a new vision for multi-purpose water resources management, which was based on the novel assumption that rivers were to be managed as bounded hydrological systems. The vision included a novel guiding principle of multi-purpose water resources management, prescribing that rivers need to be developed and managed in a systematic and consistent way, with the aim to reconcile navigation, flood control, irrigation, and hydropower. Under his presidential leadership, Hoover played a vital role in a series of political compromises that resulted in the adoption of the 1928 Flood Control Act [66]. This happened rather quickly, as the 1927 flood disaster helped him to mobilise support for the new vision and also to become elected president [70].

\subsection{Federalism and New Deal Era (1929-1967)}

\subsubsection{Landscape Developments}

The post-1928 flood control acts triggered macro-political developments that fragmented the governance landscape. These gradual developments drove public opinion in favour of strong state-based federalism, although states led in canal-building and flood control, with water issues resolved primarily at state and local levels [70]. However, the 1928 Flood Control Act made the federal government responsible for the Mississippi River, but also immunised this government from any liability of any kind and for any damage from or by floods or floodwaters at any place.

An important disruptive event was the 1929 Great Depression, which led to the 1932 presidential election of Franklin Roosevelt [66]. The New Deal continued large public works projects to alleviate poverty and unemployment between 1933 and 1936. The New Deal focused on what was called the "Three Rs" related to Relief, Recovery, and Reform: Relief for the unemployed and poor, Recovery of the economy to normal levels; and Reform of the financial system to prevent a repeated depression [74]. The New Deal is the hallmark of state-based federalism, in which new federal institutions were established to enable an integrated planning approach for regional economic development, land use development and water resources management.

\subsubsection{The Existing Regime}

The overall societal function of watershed management comprised the functions described in Section 3.3.2. In this period, the set of functions expanded with land use planning. Strong federal government was seen as a requirement for watershed management [68]. The Tennessee Valley Authority (TVA) was the first federal authority to broadly apply alternative approaches to control flood damage, choosing to add land use planning methods to the popular structural measures already used to control the paths of floodwaters. The TVA was envisioned as a blueprint for the integration of land and water as well as land use planning methods and existing measures that were already used to control the paths of floodwaters.

Meanwhile, the Corps refused to join the movement toward watershed management, preferring to conduct river management in a piecemeal fashion for the benefit of many local interests [70]. Nevertheless, federalism in water affairs, including the guiding principle, was supported by emerging technologies like concrete dam building design (e.g., the Hoover Dam and Norris Dam) that could enable multi-purpose watershed management. Multi-purpose watershed management was envisioned to strike a balance economic and environmental objectives [3]. During the Roosevelt administration, more administrative layers were added to the complicated variety of authorities for the construction 
and maintenance of flood control devices, which deviated watershed management further from Hoover's ideal of comprehensive watershed planning [66]. This ideal was reflected in the dominant guiding principle that rivers are to be treated as bounded hydrological systems and the watershed or river basin was considered the appropriate scope of management. Multi-purpose watershed required (i) government to be active and strong as markets could not be trusted to manage water resources; (ii) multipurpose and region-wide planning as exemplified by the TVA; (iii) intergovernmental coordination in flood control.

\subsubsection{Niche Developments}

In this period, there was only one niche vision on more human adjustment to floods. The vision was strongly supported and further developed by a renowned geographer and an influential proponent of an integrated planning approach, Gilbert F. White [75]. He concluded that many water problems, including floods, were the inevitable result of past human modifications of natural conditions set by the dominant guiding principle. The novel vision articulated the desired change to adjust human occupancy to the floodplain environment for effective use of the natural resources of the floodplain. Multiple human adjustments to floods or non-conventional flood control engineering measures were envisioned to protect the occupants of floodplains against floods and to aid them when they suffer from flood losses, and of encouraging more intensive use of floodplains [76].

The new vision was inspired by White's work, which assumed that floodplains were key to flood control [76]. This implied that the integration of land-use restrictions, and forecasting and warning systems had to be part of watershed management. The vision included a new guiding principle of multiple adjustments to floods, combining conventional measures (e.g., levees and dams) and non-conventional measures (e.g., floodplain abandonment and flood insurance). Due to growing concerns about increasing floodplain occupancy, White's ideas and work reached a broader audience that allowed him to play a key role in building a supporting network for the new vision and his studies. White's cost-benefit analysis received support from Harvard professor Arthur Maass, who criticised the role of the Corps in its rivers and harbour activities and introduced his theory on the economics of water resources planning [68]. Support also came from two US Geological Survey hydrologists, who revealed the major ineffectiveness of the Corps' upstream and downstream flood control measures.

White's studies received criticism from the Corps because it revealed the shortcomings of the conventional flood control engineering approach [68]. The opponents, generally from an engineering background, found White's ideas on human adjustments highly controversial, and argued he promoted un-American ideas. They were great proponents of engineering as a panacea for solving all flood management problems [77]. However, White's 1958 study Regulating Flood Plain Management and increasing loss of property and cost of flood damage, changed the course of the debate in White's favour. The new vision received federal support from the Council of State Governments and US Congress, as both were convinced that White's vision and guiding principle offered a real alternative to existing flood control practices. This led to the expansion of the Corps' role in broader flood control approaches in line with the new guiding principles. Endorsement of the recommendations of White's [78] study Choice of Adjustments to Floods by US Congress led to enactment of land-use regulations for floodplains and flood hazard evaluation guidelines for federal executive agencies [68].

\subsection{The Environmental and National Flood Insurance Era (1968-1994)}

\subsubsection{Landscape Developments}

Already five years after the enactment of the national flood insurance programme (NFIP), White's admonition was validated. Flood losses were continuing to increase due to accelerated macroeconomic developments like floodplain development [68]. The 1968 National Flood Insurance Act led to floodplain abandonment, but also triggered the perverse effect of stimulating the development of vulnerable areas and exacerbating the flood damages. Both federal flood control construction and the availability 
of federally insured loans and grants for land acquisition and building were at fault. The disruptive event of the 1993 flood revealed that the federal government's emphasis on flood insurance and local floodplain management was insufficient.

\subsubsection{The Existing Regime}

White's plea for a national flood insurance programme (NFIP) to involve federal, state and local governments and the private sector in recovering flood losses, led to the adoption of the 1968 National Flood Insurance Act. The adoption of the National Environmental Policy Act and the creation of the US Environmental Protection Agency (EPA) embodied the limitations of human occupancy in floodplains.

The overall societal function of water management comprised the functions described in Section 3.4.2. In this period, the set of functions was extended to floodplain-based flood control, which included arrangements imposed by a governing body (local, regional, or national) to restrict the use of floodplains, or flexible human adjustments to flood risk that do not involve substantial investment in flood-control engineering works [79]. The dominant guiding principle for water management was multiple adjustments to floods, combining conventional measures and non-conventional measures.

\subsubsection{Niche Developments}

In this period, there were two niche visions: (i) floodplain conservation and (ii) integrated floodplain management. The first vision emerged in the aftermath of the $1993 \mathrm{flood}$, when Congress adjusted the NFIP and authorised buy-outs for some structures and cropland in the floodplain. Congress also appointed the Special Inter-Agency Floodplain Management Review Commission to assess existing flood control programmes and make recommendations for radical change. The Commission, chaired by the former Corps Brigadier General Gerald Galloway, envisioned a more balanced approach to federal floodplain management, using both conventional (levees) and non-conventional flood-control engineering measures (wetland restoration for reduced peak flood flows). This vision differed from the dominant vision of multiple adjustments to floods, as it emphasised that more of the floodplain should be reserved for wetlands, forests and agriculture. However, the Commission failed to recognise a major role for wetlands in providing flood protection [70]. Ironically, supported by new federal legislation, some communities successfully experimented with retreating from flood-prone areas rather than resorting to yet more mainstream flood control engineering [70]. They learnt the hard lesson of the 1993 flood and realised that some floodplains are best left in their natural conditions [68].

A second niche vision on integrated natural resource management in floodplains and wetlands emerged, while the lesson on ecological restoration of floodplains at the grassroots level appeared on the radar screen of the Federal Interagency Floodplain Management Taskforce. The Taskforce's Chair, Frank Thomas, was inspired by Jon Kusler of the University of Wisconsin, who supported the new vision [68]. This vision challenged the dominant guiding principle. It emphasised the need for environmental legislation, by targeting on addressing multiple measures or problems at a time, establishing interagency coordination, preventing endless litigation, and neglect social and economic impacts [3].

The new vision was based on the assumption that functions and resources of wetlands and floodplains need to be restored in order to reduce flood losses and environmental harm. New environmental protection goals were set for federal, state, and local government agencies and interest groups and new targets were set for collaborative and integrated watershed management. The new guiding principles for watershed management included: (i) strengthening state, federal, and local wetland programmes by facilitating and improving cooperation among these governmental entities; (ii) integrating public, private, and academic efforts to achieve wetland protection and management goals; and (iii) identifying and quantifying the beneficial ecosystem functions of wetlands in order to improve their management and restoration.

Based on Kusler's effort to coordinate floodplain management and measures, the new vision rapidly acquired national attention and support to bring about changes in line with the vision. During 
the 1980s, Kusler played a key role in establishing a supportive network of representatives of the EPA's Office of Wetland Protection for the vision and to promote his work on integrating floodplain and wetland management approaches [68]. The vision was endorsed by the Corps and other federal agencies because they had to step up to their environmental commitment. These agencies internalised an ethic dedicated to environmentally friendly water resources projects. In line with the new vision, US Congress further refined and expanded the Corps' environmental reach by authorising it to protect, restore, and create aquatic and ecologically related habitat, including wetlands.

\subsection{The Watershed Collaborative Era (1995-Present)}

\subsubsection{Landscape Developments}

In New Orleans and along the Gulf Coast, a convergence of natural and human forces set the stage for predictable and predicted environmental developments such as flood catastrophes. Once again, levees proved to be insufficient to secure settlement in the floodplain, which gave rise to a gradual development like increased vulnerability to flood disasters. The Mississippi River floods in the Midwestern states led to a flurry of rebuilding within the floodplain in the 1950s and 1990s, so did the Hurricane Betsy encouraged levees support floodplain development. In 2005, Hurricane Katrina revealed many of the challenges faced by planners and managers who attempt to understand and manage flood disasters [80]. Being a disruptive event, Hurricane Katrina also demonstrated that a loss of coastal wetlands in Louisiana increased the vulnerability of the area to hurricane impacts [81].

\subsubsection{The Existing Regime}

The overall societal function of watershed management comprised the functions described in Section 3.5.2. In this period, the set of sub functions was extended to wetland-based flood control [3] (see Table 2). The dominant guiding principle was to achieve increased collaboration between federal, state, and local government agencies for environmentally sound collaborative watershed management (Section 3.5.3). Even stakeholders were considered to hold valuable local knowledge and expertise to participate in collaborative negotiations with their counterparts.

\subsubsection{Niche Developments}

In the aftermath of Katrina, the Louisiana Coastal Protection and Restoration Authority was created. This post-hurricane development was based on the recognition that wetland ecosystems, whether forested or not, are critical buffers for mitigating the impacts of hurricanes in coastal areas [80]. Although US Congress gave the Corps a specific ecosystem restoration mission in the 1990s, ecosystem restoration further complicates the problems water resource planners face $[80,82]$. A panel on adaptive management for resource stewardship served as a committee to assess the Corp's methods of analysis and peer review for water resources project planning [83]. Restoration requires an understanding of wetland ecosystems. Our understanding of these systems is limited because of their complex nature and behaviour emblematic for complex adaptive systems (Section 2.1.2), which poses uncertainties for management [84].

In the last two decades, water planners in the United States and around the world are attempting to develop "comprehensive" water management plans $[85,86]$. These niche developments are based on a vision for comprehensive water management reflecting the guiding principles for integrated water resources management (IWRM) [82,87]. However, the implementation of an IWRM approach that fully accounts for the complexity of ecosystems in watersheds has yet to be realised. New management approaches such as adaptive water management have been proposed as a promising way to deal with complexity and the related uncertainties [88,89].

There are reports on relevant niche developments in the New Orleans region. Van der Voorn et al. [42], for instance, reported on a niche development around a vision on adaptive and integrated water management. This example coincides with other on-going regional niche developments, driven by 
visions that promote integrated approaches for coastal restoration, wetland protection, and flood protection, which articulate a change towards increased disaster resilience realised through adaptation to climate change impacts. These niche developments promote a novel guiding principle, based on a learning-based approach as the key guiding principle for the fulfilment of new goals like dealing with the assumed complexities and uncertainties due to climate change.

More research is yet needed on the potential of these strategies and approaches to help addressing the types of changes and challenges. Several avenues for further research can be found in the literature. For example, Kashem et al. [90] evaluated the changing patterns of social vulnerability in New Orleans and integrated neighbourhood change theories with theories of social vulnerability. Govind [91] reported on the lesson from Katrina with managing SES in an uncertain future affected by climate change. It provides further insights as to the complementary nature of climate policy and resilience while galvanising New Orleans against future extreme events. Abadie [92] reported on an application of probabilistic weighting of Intergovernmental Panel on Climate Change scenarios to reduce sea level damage risk for New Orleans.

\section{Discussion}

\subsection{Key Findings and Patterns}

In the introduction of the paper, four transition periods were introduced which are confirmed by our historical inquiry. Another transition period (early 1800s-1889) was identified, which can be seen as the initial phase of the single purpose era as watershed management was essentially absent.

The inquiry shows that in the lower Mississippi five different periods can be identified in watershed management, which can be characterised by different guiding principles and societal functions. Results are summarised in Figure 2 and Tables 2 and 3.

$\begin{array}{ll}\text { The Manifest Destiny } & \begin{array}{l}\text { The Progressive } \\ \text { Conservation }\end{array} \\ \text { Era } & \text { Era } \\ \text { (early } 1800 s-1889) & \end{array}$

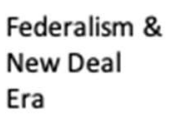

\section{Environmental \&}

Flood Insurance

Era

Watershed

(1929 - 1967)

(1968 - 1994)

collaborative

Era

(1995 - present)

Landscape level

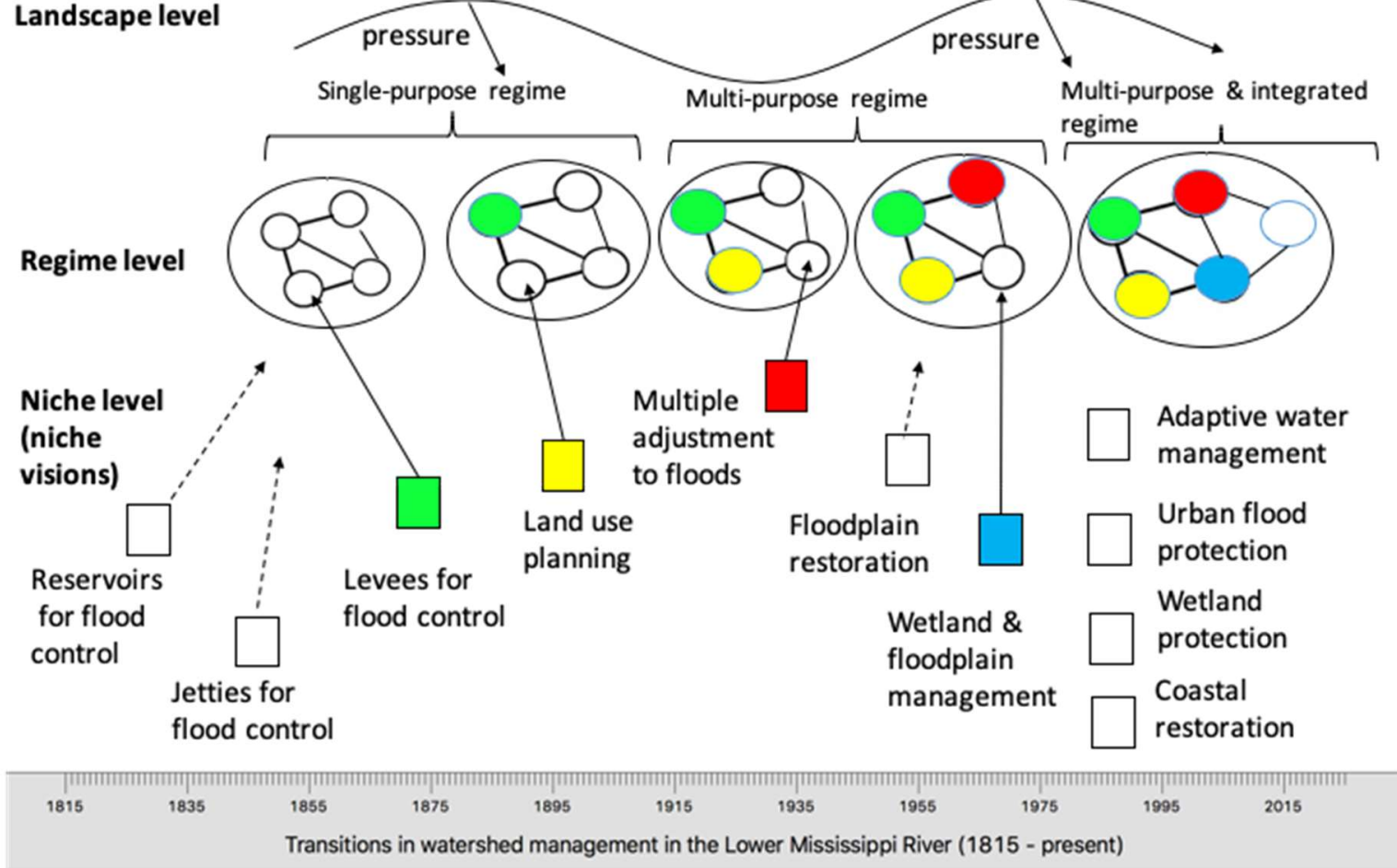

Figure 2. A chronological overview of transitions in watershed management in the Mississippi River. 
Table 3. Summary table of niche visions that became part of the regime.

\begin{tabular}{|c|c|c|c|c|c|}
\hline Criteria & $\begin{array}{c}\text { Manifest Destiny } \\
\text { Era (Early } \\
\text { 1800s-1890) }\end{array}$ & $\begin{array}{c}\text { Progressive } \\
\text { Conservation Era } \\
(1890-1928)\end{array}$ & $\begin{array}{c}\text { Federalism and } \\
\text { New Deal Era } \\
(1929-1967)\end{array}$ & $\begin{array}{c}\text { Env. \& Flood Ins. } \\
\text { Era (1968-1994) }\end{array}$ & $\begin{array}{c}\text { Watershed } \\
\text { Collaborative Era } \\
\text { (1995-Present) }\end{array}$ \\
\hline \multicolumn{6}{|c|}{ Niche vision } \\
\hline Desired change & $\begin{array}{l}\text { Secure navigation } \\
\text { through cost } \\
\text { efficient } \\
\text { 'levee-only' flood } \\
\text { control approach }\end{array}$ & $\begin{array}{l}\text { Watershed as } \\
\text { appropriate scale of } \\
\text { management }\end{array}$ & $\begin{array}{l}\text { Multiple } \\
\text { adjustments to } \\
\text { flood disasters }\end{array}$ & $\begin{array}{c}\text { Integration of } \\
\text { natural resources } \\
\text { in floodplain \& } \\
\text { wetland } \\
\text { management }\end{array}$ & $\begin{array}{l}\text { Increased disaster } \\
\text { resilience }\end{array}$ \\
\hline \multicolumn{6}{|c|}{ Guiding principle } \\
\hline $\begin{array}{l}\text { New guiding } \\
\text { principle(s) }\end{array}$ & $\begin{array}{l}\text { Flood control } \\
\text { through levees }\end{array}$ & $\begin{array}{l}\text { Multi-purpose water } \\
\text { management } \\
\text { (systematic } \\
\text { management of rivers) }\end{array}$ & $\begin{array}{c}\text { Flood control } \\
\text { engineering \& } \\
\text { multiple } \\
\text { adjustments, flood } \\
\text { insurance }\end{array}$ & $\begin{array}{l}\text { Collaborative } \\
\text { watershed } \\
\text { management for } \\
\text { integrated } \\
\text { management }\end{array}$ & $\begin{array}{l}\text { Learning based } \\
\text { management } \\
\text { approach }\end{array}$ \\
\hline \multicolumn{6}{|c|}{ Actors } \\
\hline $\begin{array}{c}\text { Vision } \\
\text { champion }\end{array}$ & A.A. Humphreys / & H. Hoover & G.F. White & J. Kusler & Not yet evident \\
\hline
\end{tabular}

Firstly, a key finding from the case study is that a cumulative pattern can be observed in which the number of societal functions increased with every transition, which led to a more extensive and complex water management regime after every transition. Whereas in the first era four functions were pursued, in the fifth era this had grown to nine functions. The water management regimes in the first two eras were single-purpose, succeeded by several multi-purpose water management regimes. Since the fifth era, the water management regime has become more integrated to strike a balance between economic and environmental objectives. At present, a transition is unfolding towards more adaptive water management regimes to better account for the complexity of SES and the related uncertainties in water management in the face of climate change. This may point to a difference to socio-technical transition research e.g., [22,93], in which the focus is on emerging technologies that provide new functions (e.g., smart phones) or provide an existing function in a more efficient or sophisticated way. By contrast, water management transitions are not driven by technological improvement, but rather mission driven. Since the 20th century, water management regimes have not only become more extensive, but also more integrated enabling managing and combining multiple and potentially conflicting societal functions. Possibly due to its public or government nature, there is also a larger discussion at play on which (public) tasks should be provided and the opportunities of new technologies is only one of the factors in a broader societal debate and political decision making see e.g., [94-96].

Secondly, external factors like landscape factors have also a major influence on the rise of a new niche vision, as they emerged as environmental, economic, social, and political pressures on the regime and created windows of opportunity for change. A similar pattern can be found in historical transitions in European land management see e.g., [65]. With regard to landscape factors, a distinction can be made between disruptive events and gradual developments. Disruptive events like flood disasters have been one of the major drivers for change. Flood disasters created windows of opportunities for new institutional developments (e.g., the development and enactment of Flood Acts), because these disasters revealed the shortcomings of dominant water management practices and the necessity for new water management solutions see e.g., [11,97]. Gradual developments that triggered change were technological, scientific, economic, and societal developments. For instance, the shift to levee-based flood control was based on new hydrological theories on river flows. The Great Depression and the subsequent New Deal programme favoured a shift to multi-purpose water resources management, which was possible through technological developments, such as concrete dam building design, and the willingness to invest in public infrastructures to mitigate the socio-economic decline due to the great depression. An example of a societal factor, is the regime response to increased environmental awareness that provoked a shift towards more environmentally sound water resources management. 
However, there is no single factor decisive in niche-driven change, but it is rather the interplay of various factors triggering change see e.g., [26,98].

Thirdly, niches and niche visions seem to play an important role in revealing the shortcomings of the prevailing guiding principle for water management. For transitions to occur, emerging visions need to trigger disruptive changes in the dominant guiding principle for water management and the development and testing of a credible, alternative guiding principle to replace the old one, both of which have been the case in all transition periods. It is unlikely that incremental changes lead to a transition, but rather to a refinement of current practices see e.g., [39].

Fourthly, if there were several niche visions present, only one vision led to a transition. No evidence for hybridisation or integration of multiple niche visions was found, though there was clearly a struggle between competing visions and their supporting networks. This may suggest that the niche visions provided competing solutions that are complementary to the regime. The analysis does not give evidence whether it was especially due to the content of the vision, or due to agency, or both. In the first era, there was a scientific base for the emerging vision, whereas the niche vision in the second era was backed by emerging technologies for water engineering. During the third era, there were no competing niche dynamics, but the vision offered a real alternative to existing flood control practices. In the fourth transition period, increased environmental awareness, which is a landscape factor, enabled the uptake of the vision. This may suggest that new developments were not decisive for the uptake of vision but rather new knowledge developments from which new guiding principles for water management emerged. These principles led to new societal functions or refurbishment of existing ones.

Moreover, all visions provided guidance and image, but the level of guidance was determined in the way agency was provided by actors. The case shows that agency is key to the further diffusion of visions and niches. The case also shows that each niche vision can be related to key actors that can be seen as vision champions, who showed rule-breaking behaviour and leadership that inspired and mobilised others. Vision champions can provide agency and were found both outside and inside the watershed management regime. For instance, both White and Kusler acted initially from outside the regime (i.e., research niche), in which they were able to develop, freely express and further mature the novel vision. For instance, both Humphreys and Hoover first became leading figures in the water management regime from which they facilitated change as well as the diffusion of a new vision. The concept of vision champion has been useful for our analysis. The presence of a vision champion does not necessarily guarantee a successful adoption of an emerging vision. The case shows that some vision champions were more successful than their counterparts because they were successfully mobilising and creating networks leading to agency. Therefore, vision champions should be seen as embedded in larger networks, in which the type of membership, role, connections, and power of actors may influence successful adoption of a vision see e.g., [50,51].

\subsection{Limitations of the Study}

Overall, the relevance of our findings may be constrained by some limitations. Our causal narratives draw on secondary sources, which are second-hand interpretations of the events under study. These sources are one or more steps removed from these events and may be biased. The use of secondary sources in the study of historical transitions has been criticised $[99,100]$, but we argue that it is still useful and allows for conclusions, though it should be noted that more detailed research into each transition using primary resources would be recommended for substantiating and validating our findings. This may lead to refining the starting and ending points of our transition periods, in which we described the landscape and regime factors that resulted in nonlinear changes in the water management regime. As causal narratives are by definition limited and narrowly defined, we are aware that other landscape and regime factors (e.g., indigenous knowledge or uses of rivers or the American history of slavery) may have intersected with emerging ideas and ways of thinking in water management. 
From a methodological perspective, one could question the relevance of our findings to current transitions towards adaptive water management. Extrapolation of historical transitions into the future suggests that the future is a continuation of the past. Transitions are, in fact, heterogeneous, long-term effects of socio-technical and social-ecological change and contingent on factors such as time scale, place, and social, environmental, political, and economic context. Extrapolation may simplify history to a linear, causal process, which projects a narrowed view on the complex and dynamic nature of water management regimes that is driven by innovation to continue its existence. This complex reductionist view neglects the role of human agency that manifests itself around short-term socio-environmental dynamics as agents, visions, and niches continuously interact in transitions. We therefore reject the idea of linear history but rather argue for adequate historical analysis, which describes the past not just as it was meant to be with logic based on ex-post insights, see e.g., Ertsen [100]. Our framework offers a heuristic device or the basis for analysing niche-driven change in water management regimes and identifying recurrent patterns in water management transitions.

Another limitation is our focus on the interaction of visions and actors in niches and less on learning processes and knowledge development, which are key to vision development and niche formation. An evaluation of learning processes could provide other explanations of why some emerging visions were more promising than others and why some actors were more successful in building a supporting network for the vision. We argue that these aspects need to be investigated in light of landscape and regime factors. In doing so, we acknowledge the potential relevance of other explanations, theories of change and realities of the complex and diverse lived experience. Molle [101], for example, described the evolution of the concept of river basin and how it has been associated with various strands of thinking and sometimes co-opted or mobilised social groups or organisations to strengthen the legitimacy of their agendas. This study provides an alternative explanation on how interconnected and nested waterscapes have been managed by discontinuous nested political, administrative, and social levels in the US and western Europe. The relevance of this study lies in its focus on realignments of power structures between the local, regional, and national levels, which have not been included in our study. We argue that power structures could enrich our historical analysis, providing further insight into the way actors provided agency e.g., what strategies did actors adopt to shape transitions, what resources did they mobilise and deploy in realising these strategies, the role actors played in transitions and how they aligned their strategies and resources to achieve common goals. Furthermore, a complementary view on power structures is provided by Swyngedouw [102], who confirmed multidimensional relationships between the socio-technical organisation of the hydro-social cycle, the associated power geometries that regulate access to and exclusion from water, as well as the uneven political power relations that affect the flows of water.

\section{Conclusions and Recommendations}

In this paper, we have developed a conceptual framework for studying the interplay of visions and actors in niche-based change in water management regimes. The framework also emphasises the importance of agency not only in advocating and developing emerging visions and niches, but also in keeping the status quo. Vision champions and niche networks are important in initiating changes that depart from an existing water management regime, which eventually may lead to its transition, as well as advocating and substantiating emerging visions. Vision champions can be found outside and inside the existing water management regime.

Overall, we conclude that water management regimes change over time through transitions. They are preceded by niche developments, in which new visions emerge and mature. The study shows that only one of these visions becomes successful in guiding transitions, in which there is no single factor or decisive development. A transition is rather the result of the interplay of a range of factors at the landscape, regime, and niche level. From our historical inquiry, we conclude the following: (i) emerging visions play an important role in guiding transitions; (ii) agency enables the further diffusion of visions and niches; (iii) vision champions play an important role in transitions, but are 
not decisive; (iv) each transition has led to an extension of the number of societal functions provided, which has led to more complex water management regimes in which functions are combined and integrated; and (v) external landscape factors are important, as they can lead to awareness and urgency in important decision making processes.

We consider our findings relevant to water management policy and transition studies. Our study provides a longitudinal study on water management transitions. It reveals the complexity of water management transitions, which are contingent on social, environmental, political, and economic factors. It enables water managers and policy makers to critically reflect upon the viability of past and current water management practices in light of vision development and experiments for adaptive water management in niches to acquire knowledge and experiences about new management practices and schemes for adaptive water management. Such niche developments need to be facilitated by water managers and policy makers to enable knowledge development and learning processes for crafting transition pathways to adaptive water management. From a research perspective, our study has relevance to transition studies, as it contributes to a better understanding of the role of visions, actors, and niches in water management transitions, which have been hitherto undertheorised in the transition literature. It demonstrates that water management transitions are not unidirectional developments, but rather path-dependent processes that may be affected by various drivers, including sudden events e.g., [65].

Regarding research recommendations, we identify the following future research avenues for transition research. Although our contribution is on the overall picture and patterns over a much longer period of time based on secondary sources, we would recommend follow-up research into primary sources for specific transitions that could shed more light on how networks emerged and the role of key persons, who can become key just because they are within a network of other actors and persons contributing in their way to the further development of the network.

In-depth research on specific transitions in the Lower Mississippi River is needed to substantiate and validate landscape and regime factors, as well as the starting and ending points of transition periods. Using primary sources can lead to more insight into other landscape and regime factors and their intersections that have been overlooked in this study. We recommend extending the research focus on evaluating learning processes and knowledge development in historical transitions and validating findings against alternative explanations and theories of change. Finally, since transitions are contingent on many factors, whether or not a transition has taken place is not a transparent matter. Neither are transitions comparable. A comparative, longitudinal analysis of other transitions cases is recommended to identify general patterns and context specific factors within different institutional contexts. A longitudinal research design is inevitable if one wants to identify whether a transition process took or is taking place, but also under which circumstances this happens. Longitudinal case studies have become a standard approach to the study of socio-technical transitions, where variables change qualitatively as well as quantitatively and where the aim is to trace processes of transformation. This methodology allows contingencies to be set against more systemic forces, and bringing to the fore the concrete, context-dependent knowledge in which different types of actors try to make sense of and participate in complex processes of change. Comprehensive transition analysis and country-comparative research on longitudinal case studies addressing multiple transitions in water management are limited, but warrant further investigation.

Author Contributions: Conceptualization, T.v.d.V. and J.Q.; methodology, T.v.d.V.; validation, T.v.d.V. and J.Q.; formal analysis, T.v.d.V. and J.Q.; investigation, T.v.d.V.; resources, University of Osnabrück.; data curation, T.v.d.V.; writing—original draft preparation, T.v.d.V. and J.Q.; writing—review and editing, T.v.d.V. and J.Q.

Funding: This research received no external funding.

Acknowledgments: The authors would like to acknowledge their gratitude to Claudia Pahl-Wostl for providing valuable feedback on the manuscript and supervision. We also thank our colleagues at The Institute of Environmental Systems Research (Christian Knieper and Bjorn Fokken), Delft University of Technology (Wil Thissen, Maurits Ertsen and Alex van Heezik) and the Dutch Ministry of Infrastructure and the Environment (Bert Toussaint), and three anonymous reviewers for providing constructive feedback and insightful discussions 
on earlier drafts of this manuscript. This research did not receive any specific grant from funding agencies in the public, commercial, or not-for-profit sectors.

Conflicts of Interest: The authors declare no conflict of interest.

\section{References}

1. White, G.F. Reflections on the 50-year international search for integrated water management. Water Policy 1998, 1, 21-27. [CrossRef]

2. Jakobsson, E. Industrialization of Rivers: A water system approach to hydropower development. Knowl. Technol. Policy 2002, 14, 41-56. [CrossRef]

3. Sabatier, P.A.; Focht, W.; Lubell, M.N.; Trachtenberg, Z.; Vedlitz, A.; Matlock, M. Swimming Upstream: Collaborative Approaches to Watershed Management; MIT Press: Cambridge, MA, USA, 2005.

4. Pahl-Wostl, C. Information, public empowerment, and the management of urban watersheds. Environ. Model. Softw. 2005, 20, 457-467. [CrossRef]

5. Holling, C.S.; Meffe, G.K. Command and control and the pathology of natural resource management. Conserv. Biol. 1996, 10, 328-337. [CrossRef]

6. Gleick, P. Global freshwater resources: Soft-path solutions for the 21st Century. Science 2003, 302, $1524-1528$. [CrossRef] [PubMed]

7. Biswas, A.K. Integrated water resources management: A reassessment. Water Int. 2004, 29, 248-256. [CrossRef]

8. Pahl-Wostl, C.; Sendzimir, J.; Jeffrey, P.; Aerts, J.; Berkamp, G.; Cross, K. Managing change toward adaptive water management through social learning. Ecol. Soc. 2007, 12, 30. [CrossRef]

9. Pahl-Wostl, C. Transitions towards adaptive management of water facing climate and global change. Water Resour. Manag. 2007, 21, 49-62. [CrossRef]

10. Huntjens, P.; Pahl-Wostl, C.; Grin, J. Climate change adaptation in European river basins. Reg. Environ. Chang. 2010, 10, 263-284. [CrossRef]

11. Xia, C.; Pahl-Wostl, C. Understanding the development of flood management in the middle Yangtze River. Environ. Innov. Soc. Transit. 2012, 5, 60-75. [CrossRef]

12. Weaver, P.; Jansen, L.; Van Grootveld, G.; Van Spiegel, E.; Vergragt, P. Sustainable Technology Development; Greenleaf: Shefield, UK, 2000.

13. Quist, J. Backcasting for a Sustainable Future: The Impact after Ten Years; Eburon: Delft, The Netherlands, 2007.

14. Berkhout, F. Normative expectations in systems innovation. Technol. Anal. Strateg. Manag. 2006, 18, $299-311$. [CrossRef]

15. Loorbach, D.; Rotmans, J. Managing transitions for sustainable development. In Understanding Industrial Transformation: Views from Different Disciplines; Olsthoorn, X., Wieckzorek, A., Eds.; Springer: Dordrecht, The Netherlands, 2006; pp. 187-206.

16. Sondeijker, S.; Geurts, J.; Rotmans, J.; Tukker, A. Imagining sustainability: The added value of transition scenarios in transition management. Foresight 2006, 8, 15-30. [CrossRef]

17. Loorbach, D.; Frantzeskaki, N.; Avelino, F. Sustainability transitions research: Transforming science and practice for societal change. Annu. Rev. Environ. Resour. 2017, 42, 599-626. [CrossRef]

18. Van der Helm, R. The vision phenomenon: Towards a theoretical underpinning of visions of the future and the process of envisioning. Futures 2009, 41, 96-104. [CrossRef]

19. Grin, J.; Rotmans, J.; Schot, J.; Geels, F.; Loorbach, D. Transitions to Sustainable Development: New Directions in the Study of Long Term Transformative Change; Routledge: New York, NY, USA; London, UK, 2010.

20. Rip, A.; Kemp, R.P.M. Technological change in human choice and climate change. Resour. Technol. 1998, 2, 327-399.

21. Loorbach, D.; Rotmans, J. The practice of transition management: Examples and lessons from four distinct cases. Futures 2010, 42, 237-246. [CrossRef]

22. Geels, F.W. Technological transitions as evolutionary reconfiguration processes: A multi-level perspective and a case-study. Res. Policy 2002, 31, 1257-1274. [CrossRef]

23. Geels, F.W. From sectoral systems of innovation to socio-technical systems: Insights about dynamics and change from sociology and institutional theory. Res. Policy 2004, 33, 897-920. [CrossRef]

24. Van der Brugge, R.; Rotmans, J. The transition in Dutch water management. Reg. Environ. Chang. 2005, 5, 164-176. [CrossRef] 
25. Holtz, G.; Brugnach, M.; Pahl-Wostl, C. Specifying "regime"-A framework for defining and describing regimes in transition research. Technol. Forecast. Soc. Chang. 2008, 75, 623-643. [CrossRef]

26. Geels, F.W.; Schot, J. Typology of sociotechnical transition pathways. Res. Policy 2007, 36, 399-417. [CrossRef]

27. Quist, J.; Thissen, W.; Vergragt, P.J. The impact and spin-off of participatory backcasting: From vision to niche. Technol. Forecast. Soc. Chang. 2011, 78, 883-897. [CrossRef]

28. Hoogma, R. Exploiting Technological Niches: Strategies for Experimental Introduction of Electric Vehicles. Ph.D. Thesis, Universiteit Twente, Enschede, The Netherlands, 2000.

29. Van de Bosch, S. Transition Experiments. Exploring Societal Changes towards Sustainability. Ph.D. Thesis, Erasmus Universiteit Rotterdam, Rotterdam, The Netherlands, 2010.

30. Raven, R.P.J.M. Strategic Niche Management for Biomass. Ph.D. Thesis, Eindhoven University of Technology, Eindhoven, The Netherlands, 2005.

31. Smith, A.; Stirling, A. The politics of social-ecological resilience and sustainable socio-technical transitions. Ecol. Soc. 2010, 15, 11. [CrossRef]

32. Folke, C.; Hahn, T.; Olsson, P.; Norberg, J. Adaptive governance of social-ecological systems. Annu. Rev. Environ. Resour. 2005, 30, 441-473. [CrossRef]

33. Fuenfschilling, L.; Truffer, B. The interplay of institutions, actors and technologies in socio-technical systems-An analysis of transformations in the Australian urban water sector. Technol. Forecast. Soc. Chang. 2016, 103, 298-312. [CrossRef]

34. Farla, J.; Markard, J.; Raven, R.; Coenen, L. Sustainability transitions in the making: A closer look at actors, strategies and resources. Technol. Forecast. Soc. Chang. 2012, 79, 991-998. [CrossRef]

35. Folke, C.; Carpenter, S.; Walker, B.; Scheffer, M.; Elmqvist, T.; Gunderson, L.; Holling, C.S. Regime shifts, resilience, and biodiversity in ecosystem management. Annu. Rev. Ecol. Evol. Syst. 2004, 35, 557-581. [CrossRef]

36. Berkes, F.; Folke, C. Linking Social and Ecological Systems: Management Practices and Social Mechanisms for Building Resilience; Cambridge University Press: New York, NY, USA, 1998; Volume 4.

37. Walker, B.; Holling, C.S.; Carpenter, S.R.; Kinzig, A. Resilience, adaptability and transformability in social-ecological systems. Ecol. Soc. 2004, 9, 5. [CrossRef]

38. Fischer-Kowalski, M. Socioecological Transitions in Human History and Present, and Their Impact upon Biodiversity, Presentation to the Second ALTER-Net Summerschool; Klagenfurt University: Vienna, Austria, 2007.

39. Pahl-Wostl, C.; Jeffrey, P.; Isendahl, N.; Brugnach, M. Maturing the new water management paradigm: Progressing from aspiration to practice. Water Resour. Manag. 2011, 25, 837-856. [CrossRef]

40. Smith, A.; Stirling, A.; Berkhout, F. The governance of sustainable socio-technical transitions. Res. Policy 2005, 34, 1491-1510. [CrossRef]

41. Rotmans, J.; Kemp, R.; Van Asselt, M. More evolution than revolution: Transition management in public policy. Foresight 2001, 3, 15-31. [CrossRef]

42. Van der Voorn, T.; Quist, J.; Pahl-Wostl, C.; Haasnoot, M. Envisioning robust climate change adaptation futures for coastal regions: A comparative evaluation of cases in three continents. Mitig. Adapt. Strateg. Glob. Chang. 2017, 22, 519-546. [CrossRef]

43. Van der Voorn, T.; Pahl-Wostl, C.; Quist, J. Combining backcasting and adaptive management for climate adaptation in coastal regions: A methodology and a South African case study. J. Futures 2012, 44, 346-364. [CrossRef]

44. Grin, J. Vision assessment to support shaping 21st century society? Technology Assessment as a tool for political judgement. In Vision Assessment, Shaping Technology in the 21st Century: Towards a Repertoire for Technology Assessment; Grin, J., Grunwald, A., Eds.; Springer: Berlin, Germany, 2000; pp. 9-30.

45. Quist, J.; Knot, M.; Young, W.; Green, K.; Vergragt, P. Strategies towards sustainable households using stakeholder workshops and scenarios. Int. J. Sustain. Dev. 2001, 4, 75-89. [CrossRef]

46. Avelino, F.; Wittmayer, J.M. Shifting power relations in sustainability transitions: A multi-actor perspective. J. Environ. Policy Plan. 2016, 18, 628-649. [CrossRef]

47. Pesch, U. Tracing discursive space: Agency and change in sustainability transitions. Technol. Forecast. Soc. Chang. 2015, 90, 379-388. [CrossRef]

48. Dierkes, M.; Hoffmann, U.; Marz, L. Visions of Technology: Social and Institutional Factors Shaping the Development of New Technologies; Campus Verlag/St.Martin's Press: Frankfurt, Germany; New York, NY, USA, 1996. 
49. Dierkes, M.; Hoffmann, U.; Marz, L. Leitbild und Technik: Zur Entstehung und Steuerung technischer Innovationen; Wissenschaftszentrum Berlin fur Socialforschung, Rainer Bohn Verlag: Berlin, Germany, 1992.

50. Huitema, D.; Lebel, L.; Meijerink, S. The strategies of policy entrepreneurs in water transitions around the world. Water Policy 2011, 13, 717-733. [CrossRef]

51. Huitema, D.; Meijerink, S. Realizing water transitions: The role of policy entrepreneurs in water policy change. Ecol. Soc. 2010, 15, 26. [CrossRef]

52. Meijerink, S.; Huitema, D. Policy entrepreneurs and change strategies: Lessons from sixteen case studies of water transitions around the globe. Ecol. Soc. 2010, 15, 21. [CrossRef]

53. Hughes, T.P. Networks of Power: Electrification in Western Society, 1880-1930; John Hopkins University Press: Baltimore, MD, USA, 1983.

54. Van de Poel, I. On the role of outsiders in technical development. Technol. Anal. Strateg. Manag. 2000, 12, 383-397. [CrossRef]

55. Ligtvoet, A.; Cuppen, E.; Di Ruggero, O.; Hemmes, K.; Pesch, U.; Quist, J.; Mehos, D. New future perspectives through constructive conflict: Exploring the future of gas in the Netherlands. Futures 2016, 78-79, 19-33. [CrossRef]

56. Cuppen, E.; Breukers, S.; Hisschemöller, M.; Bergsma, E. Q methodology to select participants for a stakeholder dialogue on energy options from biomass in the Netherlands. Ecol. Econ. 2010, 69, 579-591. [CrossRef]

57. Mahoney, J. Strategies of causal assessment in comparative historical analysis. In Comparative Historical Analysis in the Social Sciences; Mahoney, J., Rueschemeyer, D., Eds.; Cambridge University Press: Cambridge, UK, 2003.

58. Ragin, C. The Comparative Method: Moving beyond Qualitative and Quantitative Strategies; University of California Press: Berkeley, CA, USA, 1989.

59. Van der Voorn, T. Future prospects for adaptive water resources management. In Bridges over Troubled Water; Wynants, M., Nuyttens, G., Eds.; VUB Press: Brussel, Belgium, 2012.

60. Pedriana, N. Rational choice, structural context, and increasing returns: A strategy for analytic narrative in historical sociology. Sociol. Methods Res. 2005, 33, 349-382. [CrossRef]

61. Geels, F.W. The multi-level perspective on sustainability transitions: Responses to seven criticisms. Environ. Innov. Soc. Transit. 2011, 1, 24-40. [CrossRef]

62. Geels, F.; Raven, R. Non-linearity and expectations in niche-development trajectories: Ups and downs in Dutch biogas development (1973-2003). Technol. Anal. Strateg. Manag. 2006, 18, 375-392. [CrossRef]

63. Geels, F.W. The dynamics of transitions in socio-technical systems: A multi-level analysis of the transition pathway from horse-drawn carriages to automobiles (1860-1930). Technol. Anal. Strateg. Manag. 2005, 17, 445-476. [CrossRef]

64. Verbong, G.; Geels, F. The ongoing energy transition: Lessons from a socio-technical, multi-level analysis of the Dutch electricity system (1960-2004). Energy Policy 2007, 35, 1025-1037. [CrossRef]

65. Jepsen, M.R.; Kuemmerle, T.; Müller, D.; Erb, K.; Verburg, P.H.; Haberl, H.; Vesterager, J.P.; Andrič, M.; Antrop, M.; Austrheim, G.; et al. Transitions in European land-management regimes between 1800 and 2010. Land Use Policy 2015, 49, 53-64. [CrossRef]

66. Barry, J.M. Rising Tide: The Great Mississippi Flood of 1927 and How It Changed Americ; Simon \& Schuster: New York, NY, USA, 1998.

67. Lonnquest, J.C.; Toussaint, B.; Manous, J.; Ertsen, M. Two Centuries of Experience in Water Resources Management: A Dutch-U.S. Retrospective; Institute for Water Resources, US Army Corps of Engineers, Rijkswaterstaat, Ministry of Infrastructure and the Environment: Alexandra, VA, USA, 2014.

68. Wright, J.M. The Nation's Responses to Flood Disasters. A Historical Account; The Association of State Floodplain Managers: Madison, WI, USA, 2000.

69. Wang, G.; Mang, S.; Cai, H.; Liu, S.; Zhang, Z.; Wang, L.; Innes, J.L. Integrated watershed management: Evolution, development and emerging trends. J. For. Res. 2016, 27, 967-994. [CrossRef]

70. Klein, C.A.; Zellmer, S.B. Mississippi River stories: Lessons from a century of unnatural disasters. South. Methodist Univ. Law Rev. 2007, 60, 1471. [CrossRef]

71. Reuss, M.; Andrew, A. Humphreys and the development of hydraulic engineering: Politics and technology in the Army Corps of Engineers, 1850-1950. Technol. Cult. 1985, 26, 1-33. [CrossRef]

72. McCool, D.C. The river commons: A new era in U. S. water policy. Univ. Tex. Law Rev. 2005, 83, $1903-1927$. 
73. Powell, J.W. Report on the Lands of the Arid Region of the United States with a More Detailed Account of the Lands of Utah; Government Printing Office: Washington, DC, USA, 1878.

74. Potter, J. The new deal: Success or failure? In The American Economy between the World Wars; Macmillan Education: London, UK, 1985.

75. Platt, R.H. Sharing the challenge: Floodplain management into the 21st Century. Environ. Sci. Policy Sustain. Dev. 1995, 37, 25-28. [CrossRef]

76. White, G.F. Human Adjustment to Floods; University of Chicago: Chicago, IL, USA, 1945.

77. MacDonald, N.; Chester, D.; Hooke, J.; Sangster, H.; Todd, B. The significance of Gilbert F. White's 1942 Paper 'Human Adjustments to floods' in the development of risk and hazard management. Prog. Phys. Geogr. 2012, 36, 125-133. [CrossRef]

78. White, G.F. Choice of Adjustment to Floods; Research Paper No. 93; Department of Geography, University of Chicago: Chicago, IL, USA, 1964.

79. Tobin, G.; Montz, B. Natural Hazards: Explanation and Integration; Guilford Press: New York, NY, USA, 1997.

80. Gunderson, L. Ecological and human community resilience in response to natural disasters. Ecol. Soc. 2010, 15, 18. [CrossRef]

81. Day, J.W.; Boesch, D.F.; Clairain, E.J.; Kemp, G.P.; Laska, S.B.; Mitsch, W.J.; Orth, K.; Mashriqui, H.; Reed, D.J.; Shabman, L.; et al. Restoration of the Mississippi Delta: Lessons from hurricanes Katrina and Rita. Science 2007, 315, 1679-1684. [CrossRef] [PubMed]

82. Reuss, M. Ecology, planning, and river management in the United States: Some historical reflections. Ecol. Soc. 2005, 10, 34. [CrossRef]

83. Council, N.R. Adaptive Management for Water Resources Project Planning; The National Academies Press: Washington, DC, USA, 2004; p. 137. [CrossRef]

84. Wallis, P.J.; Ison, R.L. Appreciating institutional complexity in water governance dynamics: A case from the Murray-Darling Basin, Australia. Water Resour. Manag. 2011, 25, 4081-4097. [CrossRef]

85. Gleick, P.H. The changing water paradigm: A look at twenty-first century water resource development. Water Int. 2000, 25, 127-138. [CrossRef]

86. Ballweber, J.A. A comparison of IWRM Frameworks: The United States and South Africa. J. Contemp. Water Res. Educ. 2006, 135, 74-79. [CrossRef]

87. Kauffman, G.J. Governance, policy, and economics of intergovernmental river basin management. Water Resour. Manag. 2015, 29, 5689-5712. [CrossRef]

88. Jacobson, C.; Hughey, K.F.D.; Allen, W.J.; Rixecker, S.; Carter, R.W. Toward more reflexive use of adaptive management. Soc. Nat. Resour. 2009, 22, 484-495. [CrossRef]

89. Godden, L.; Ison, R.L.; Wallis, P.J. Water governance in a climate change world: Appraising systemic and adaptive effectiveness. Water Resour. Manag. 2011, 25, 3971-3976. [CrossRef]

90. Kashem, S.B.; Wilson, B.; Van Zandt, S. Planning for climate adaptation: Evaluating the changing patterns of social vulnerability and adaptation challenges in three coastal cities. J. Plan. Educ. Res. 2016, 36, 304-318. [CrossRef]

91. Govind, P.J. Looking forward 10 years after Katrina: Managing climate risk and uncertainty through building systematic resilience in New Orleans post Hurricane Katrina. Int. J. Emerg. Manag. 2016, 12, 284-303. [CrossRef]

92. Abadie, L.M. Sea level damage risk with probabilistic weighting of IPCC scenarios: An application to major coastal cities. J. Clean. Prod. 2018, 175, 582-598. [CrossRef]

93. Geels, F.W. Processes and patterns in transitions and system innovations: Refining the co-evolutionary multi-level perspective. Technol. Forecast. Soc. Chang. 2005, 72, 681-696. [CrossRef]

94. Bos, J.J.; Brown, R.R.; Farrelly, M.A. Building networks and coalitions to promote transformational change: Insights from an Australian urban water planning case study. Environ. Innov. Soc. Transit. 2015, 15, 11-25. [CrossRef]

95. De Haan, F.J.; Rogers, B.C.; Frantzeskaki, N.; Brown, R.R. Transitions through a lens of urban water. Environ. Innov. Soc. Transit. 2015, 15, 1-10. [CrossRef]

96. Rogers, B.C.; Brown, R.R.; de Haan, F.J.; Deletic, A. Analysis of institutional work on innovation trajectories in water infrastructure systems of Melbourne, Australia. Environ. Innov. Soc. Transit. 2015, 15, 42-64. [CrossRef]

97. Wiering, M.A.; Arts, B.J.M. Discursive shifts in Dutch river management: 'deep' institutional change or adaptation strategy? Hydrobiologia 2006, 565, 327-338. [CrossRef] 
98. Geels, F.W.; Kemp, R. Dynamics in socio-technical systems: Typology of change processes and contrasting case studies. Technol. Soc. 2007, 29, 441-455. [CrossRef]

99. Genus, A.; Coles, A.-M. Rethinking the multi-level perspective of technological transitions. Res. Policy 2008, 37, 1436-1445. [CrossRef]

100. Ertsen, M.W.; Murphy, J.T.; Purdue, L.E.; Zhu, T. A journey of a thousand miles begins with one small step-human agency, hydrological processes and time in socio-hydrology. Hydrol. Earth Syst. Sci. 2014, 18, 1369-1382. [CrossRef]

101. Molle, F. River-basin planning and management: The social life of a concept. Geoforum 2009, 40, 484-494. [CrossRef]

102. Swyngedouw, E. The political economy and political ecology of the hydro-social cycle. J. Contemp. Water Res. Educ. 2009, 142, 56-60. [CrossRef]

(C) 2018 by the authors. Licensee MDPI, Basel, Switzerland. This article is an open access article distributed under the terms and conditions of the Creative Commons Attribution (CC BY) license (http://creativecommons.org/licenses/by/4.0/). 